\author{
ROCZNIKI HUMANISTYCZNE \\ $\frac{\text { Tom LXIX, zeszyt } 6-2021}{\text { ZESZYT SPECJALNY }}$ \\ DOI: https://doi.org/10.18290/rh21696s-10
}

ANNA WILECZEK

\title{
(NON)PANDEMIC YOUTH SPEAK. \\ ON LEXICAL-SEMANTIC TENDENCIES \\ IN THE POLISH LANGUAGE OF THE YOUTH
}

\section{INTRODUCTION}

One of the most "influential" varieties of the contemporary language is its colloquial register, considered to be the "central style of contemporary Polish" (Bartmiński 33) and a repository of tools for commonsense appreciation of reality. Language colloquialism ensures not only simplicity and specificity of communication but also provides new "tools" for a dynamic interpretation of the world, marking emotions, maintaining contact within a specific community, creating the image of the sender or marking humour. In this context, the contemporary informality, seen as the "vital force of colloquialism" (KlusStańska 72), permeating the varieties of contemporary discourses, justifies their inclusion into slang varieties, which seem closer to the specific and current experiences of users. A special role is assigned to such linguistic manifestations that are inscribed by young people into current patterns or cultural preferences. On the one hand, postmodernity awakens the need for "eternal youth" and on the other hand it allows for extreme emotionality (Klimczyk) as a function of the diverse, exciting and the strongest possible experiencing of the world. Consequently, in this context the social register of teenagers, known as youth speak, becomes the subject of special interpretative efforts.

Dr hab. ANNA WILECZEK, prof. UJK - kierownik Zakładu Badań nad Dyskursem w Instytucie Literaturoznawstwa i Językoznawstwa Uniwersytetu Jana Kochanowskiego w Kielcach; adres do korespondencji: Uniwersytet Jana Kochanowskiego, Wydział Nauk Humanistycznych, ul. Uniwersytecka 17, 25-406 Kielce; e-mail: anna.wileczek@ujk.edu.pl; ORCID: https://orcid.org/ 0000-0002-9851-6114. 


\section{BACKGROUND, OBJECTIVE AND METHODOLOGICAL ASSUMPTIONS}

The term youth speak is usually used to refer to the way young people communicate in informal situations, i.e., outside the language of school education and outside of situations requiring an official register. The synonyms of youth speak include youth biolect (if the age of teenagers is taken into account), sociolect (if the emphasis is on the social bond among young people) or slang (if expressive, creative and ludic style of communication among young people is analysed) (Wileczek, Kod młodości 67-82). The concept of slang as an expressive and at the same time ludic use of language by young people (cf. Grabias, Widawski) does not apply only to the spoken variety. This happens when, due to the prevalence of digital communication (especially during the pandemic) the "written speech" has become equally, if not more, important (Wileczek, Język i komunikacja 63-64). Consequently, the present article will focus not only on language (more precisely a specific lexical resource) and the rules of its use in a given environment but also cultural strategies which accompany unofficial communication of young people. Cultural connotations of youth, such as fun, humour, ease, contesting the applicable norms, tendency to behave in an extreme way, activated when one uses youth speak (Czarnecka 50) serve as tools for self-identification and coining new words within a specific community (Wileczek, Język i komunikacja 92-93) both in spontaneous communication and in the context of media and literary stylizations. Youth speak responds perfectly to the post-modern cultural "needs" related to the cult of youth, the apotheosis of freedom, ludic and emotional attitude towards the world and to collecting extreme experiences. It carries information about life activity, spontaneity, openness and aesthetic contestation that not only adolescents identify with. Thus, this uniquely spontaneous, unofficial and creative variation of language should show its adherence to the colloquialism and the everyday specifics because it is where it comes from. It seems that it should record those phenomena that directly and severely affect young people. Most probably everything that is related to the consequences of the SARS-CoV-2 pandemic, the disturbance of the way young people function in a space marked by such values as freedom of choice, diversity of relationships, multiple identities, recentivism, and ecstatic consumption should affect the way the world is perceived linguistically. Thus, lexis, as a linguistic marker of cultural changes, may become an "access point" to the ways in which the pandemic world is perceived by young people. 
The objective of the present article is to show how young people "tame" a pandemic reality. The analysis concentrates on the following research questions: Is the domination of the pandemic in social and economic life reflected in lexical and semantic tendencies in the Polish language used by the youth? And if so, what is the nature of the changes and how do they affect the extra-linguistic reality?

The search for answers to the indicated questions takes place through the lexical-semantic analysis, references to statistical data (frequency of submissions) and analysis of texts - the effects of unofficial youth discourse - available on the Internet.

The phenomena that will be discussed in the article are universal and refer to postmodern culture in general. The article focuses on examples from the Polish language and presents the state of contemporary Polish youth speak from the socio-cultural aspect, referring both to databases (Youth Word of the Year contest), lexicographic databases (Miejski.pl dictionary of slang) and to discursive uses (examples from colloquial discourse). The choice of the indicated sources is dictated by their topicality. As in Germany and the Czech Republic, the contest of the Youth Word of the Year, organized for the past five years by PWN Publishing House in cooperation with linguists researching youth speak, is very popular (the author of the article is a member of the jury of the contest). In 2019, nearly 42 thousand submissions were sent electronically whereas in 2020 the number reached 195 thousand. ${ }^{1}$ Each year, the contest generates several thousand media reports and the winning words become widely known and penetrate into social discourse as well as colloquial communication. Not only new or relatively new words are submitted but also those which are very popular or are promoted as "flagship words" (Pisarek) of specific Internet communities.

Miejski.pl is a 14-year-old online dictionary of youth slang that records lexical and semantic units and examples of their use based on direct submissions from natural language users. Currently, the dictionary contains 20,563 entries and 26,012 definitions. As it is an online lexical database, it collects primarily supra-regional structures (there is only a small percentage of local units) of "inter-dialectal" nature (concerning their universality). The word "urban" in this case cannot be treated as an attribute of the lexicon of a specific urban dialect (a form of the spoken language of the urban population as opposed to rural variations) as it suggests rather colloquial status of the

\footnotetext{
${ }^{1}$ I would like to thank the organizers - PWN Publishing House — for making the material available.
} 
variation, unrelated to either the cultural dialect or folk dialects. As stated above, there is no need to consider a special distinction into "speaking" and "writing", as the equality of forms and the media of communication among contemporary young people makes these indicators less important. The pandemic lockdown has strengthened the belief in the naturalness of the Internet "written speak" which has dominated the colloquial youth discourse, instantly making new words popular. Lexical material obtained from the indicated sources, including the examples of its use, has been analysed statistically (frequency of submissions) as well as culturally and linguistically (semantic examples) and therefore may be used to determine the main directions of lexical development of contemporary youth speak.

\section{LINGUISTIC MARKERS OF THE PANDEMIC}

Although coining new terms by young people is stimulated by global events (the SARS-CoV-2 pandemic) that have been setting patterns of social behaviour for over a year, compared to the number of all submissions the pandemic lexis does not constitute a significant share. Submissions of structures including the suffixes corona-/ korona-/ corono- (1703) and covid-/ cowid- (261) constitute only $1 \%$ of all Youth Word of the Year proposals for the year 2020. It therefore seems that this area of reality is not an attractive source of lexical quests for young people. The hybrids such as koronagedon (corona and Armageddon) and koronopanika (corona and panic) are rare and refer to the catastrophic experience of a pandemic in an existential dimension strengthening the fear of extinction. The effect of the conceptualization of the pandemic are neologisms occurring also in a general language variation, such as: corona/korona, diminutive koronka or some compounds which use different spelling, e.g., koronavirus, koronawajrus or mock the reality koronaświrus (corona freak) and koronaświrować (freaking out because of the coronavirus). Their expressive and mocking features mark an ironic interpretation of the state of threat. A similar semantic redundancy is demonstrated by forms such as plandemia (suggesting that the entire pandemic was planned - a plan and pandemic) or kwarantyna, which use the play of the word form (see kwarantanna [quarantine]) to negatively nominate the phenomenon. Another neosemantism, kaganiec (muzzle) 'mask' - related to the original meaning of a "wire or leather braid put on an animal' mouth" (PWN Dictionary of the Polish Language) - connotes semantic elements such as incapacitation, discomfort or dehumanization. 
Within the pandemic vocabulary it is also possible to indicate words referring to online learning as an institutional consequence of the global pandemic, e.g., być na zdalu, zdalka ([in] remote learning). Young people, leaving the buildings of schools during the pandemic restrictions (see also the word in its plural form-lockdowny (lockdowns) moved to the so-called koronaszkota or covidszkoła (corona-school). Thus, in the community vocabulary, neologisms appeared, the meaning of which refers to this institution. The research showed that the nominations of the school reality are currently extremely rare (Wileczek, Kod mtodości czy kod mlodych). Online education, which is dealt with by young people in a much better way than by teachers, led to innovations referring to free time: koronaferie, koronawakacje (corona-holidays), koronatime (corona-time), koronalia (corona + juwenalia [students' annual carnival]). As in the general language, the language of young people included words such as koronaparty (corona-party) 'unofficial meeting', or koronatrip (corona-trip) 'trip or expedition during lockdown'.

In the adolescent image of the pandemic world there are also numerous expressive terms referring to social actors. The representatives of the generation facing the pandemic are called koronialsi (the same suffix is used in the word millenialsi (millennials)). Among them there are covidziarze/covidziaki/ covidziary (those recognizing the threat of the pandemic) as well as koronasceptycy (corona-sceptics) and antycovidowcy/antycovidziarze (Covid-conspiracists) as well as covidianie (this Polish word alludes to reptilianiereptilians) or covidoci ${ }^{2}$ (those who deny or disregard the virus - a blend of covid and idiot). People who openly contest the restrictions are called koronaidioci (corona-idiots) or vulgarly koronazjeby (corona-creeps).

It should be remembered that the electronic communication of young people is multi-modal. Thus, it abounds in iconic, memetic, or viral structures which are semantic units entering a language just like "winged words"semantic constructs duplicated due to their conventional meaning. The same happens in the case of emoticons and emoji related to the time of the pandemic. Among the 1,809 iconic signs available in instant messaging there are also those concerning the coronavirus (a microbe), social distancing (a face wearing a mask), well-being (a sneezing face, runny nose, nausea, vomiting or fever). Nevertheless, statistical analyses of tweets related to coronawirus/koronawirus show that the indicated signs do not dominate the

\footnotetext{
${ }^{2}$ The different forms cov-/cow result from the unstable form of the morpheme borrowed into Polish and the specific nature of the Internet - the third variation of language (apart from speaking and writing), the so-called "recorded speech" (Wileczek, Język $i$ komunikacja).
} 
communication in the times of the pandemic because emoji expressing amusement (laugh until you cry) are more popular than a face wearing a mask (see Majchrzyk).

The above examples show that the lexis of young people records primarily the effects of colloquial and common-sense conceptualization of the pandemic and the reaction of the young generation to it. Moreover, this reaction is by no means exaggerated. Young people use elements of black humour in a provocative way, comparing restrictions and isolation as well as the lack of regular classes at school to holidays, celebrations, free time without traditional duties. What is directly related to the linguistics standards of passing through young age, e.g., bipolar valorizations, unrestricted expression, peer relations or emotional attribution seems much more attractive.

\section{ONYMIC DERIVATIVES}

The dominating tendencies which occur in the youngest version of the Polish language are related to the pragmatic function of the analysed language register. Colloquial language provides a perfect diagnosis of socio-cultural behaviour as well as an interpretation of the observed reality at the same time outlining an emotive attitude towards it. There would be nothing unusual in it, after all, slang variations have always been expressive, if not the expansion of neologisms and onimic neosemantisms. The most popular words submitted to the Word of the Year Contest (MSR 2020) included the eponym sasin or jeden sasin - "an ironic definition of a financial unit which equals the amount spent by a politician (Jacek Sasin) on the so-called envelope elections in 2020, which ultimately did not take place" (approximately 41,000 submissions)and julka/julki z Twittera (Jolka is a popular Polish girl name) 'a mocking term for a young, well-to-do, progressive female activist' (35,000 submissions), which constitutes about $25 \%$ of all submissions. Thus, the name of a well-known politician and a name that is common among teenagers are used for mocking and stigmatizing criticism.

This tendency follows the common propensity to semantize proprial structures, as evidenced by lexemes in colloquial Polish, such as janusz, grażyna, oskar, seba/sebix, czesiek (referring to popular Polish names which have become a hyperbolised image of the mindset of typical Polish bumpkins and wanglers) etc. This popular lexical-semantic model is based on a metonymic scheme. A surname, first name or name cease to be index (non-semantic) signs 
and become common nouns usually referring to a synthetic or stereotypical conceptual scheme: $X$ is a state of mind (cf. Obserwatorium). Then, they connote appellative content, using metaphorical adherence to the cultural, political, or social context. For example, the first name Janusz has come to denote a stereotypical Pole (the so-called janusz) conceptualized in several areas:

- appearance (plain, middle-aged, often with a mustache, tastelessly dressed);

- intellect (not very smart, with superficial knowledge, "picnic" football fan, lover of disco polo music);

- character (simplistic or crude sense of humour);

- behaviour (unsophisticated manners) (source: "Młodzieżowe Słowo Roku” 2020).

The repertory of youth speak also includes other derivatives: 1) januszowanie 'behaviour which is inappropriate in certain circumstances' or signs of such behaviour based on the mock form of names in the nominative case; 2) janusze biznesu (mocking the non-existent "The Janusz of Business" Award), janusze budownictwa (the Janusz of Building Construction), janusze nauki (the Janusz of Science), etc., denoting "people who are not creative, who follow stereotypes, or who are dishonest (corrupt) in their work/profession".

This principle can also be observed in other neologisms, in which the new type of inflection becomes an exponent of appelativization (Skudrzyk and Urban). Examples of this principle include the verbs chajzerować, górniakować, hajtować, (z) sasinić, spewuenić of associative semantics derived from various proper names. They contain an element of emotive evaluation, usually negative, of a person or institution while referring to attitudes, behaviour or regularities. The use of proper names and neologisms derived from names as appellatives for stereotyping is therefore quite common in the analysed communication style. "Young words" allow for developing a valorising order of social reality, however, largely according to co-figurative (parallel) patterns.

\section{WORD FIGHT}

The method of direct, aggressive valorisation of people and their behaviour is in line with the trend of "word fights", which is also manifested in the social dimension (gender fight/struggle). To a large extent, this regularity affects people who "stand out" from the group pattern, such as: alternatywka (from Polish alternatywa (alternative) 'a girl who stands out from a group because of her clothes or beliefs', jesieniara (from Polish jesien - autumn) 'exalted 
lover of autumn', mirabelka (literally: mirabelle plum) 'a female user of the website wykop.pl' or karyna (from English girl's name Karen) 'a pathological young woman'. To this end, young language users apply not only typical word-formation patterns but also linguistic or spelling plays, e.g., an incorrect spelling of $\mathrm{maDka}$ 'a demanding young mother' and $\mathrm{pOlka}$ 'a young woman putting herself in the centre of the world'. One should also note an upward trend in the production of neologisms with the suffix -ara, which was used for sexists stigmatization of women (blachara 'corruptible materialist', zmywara 'housewife - pejoratively') and today are used as mocking terms for young people fascinated by a specific area of life (e.g., goldeniara 'a fan of British singer Harry Styles and his single entitled Golden', malfojara 'a female fan of Draco Malfoy, a fictional character from the book about Harry Potter', $k$-popiara 'female fans of K-pop' as well as rzepiara 'a woman photographed against a rapeseed field', jezusiara 'a follower/lover of Jesus', koniara 'a female lover of horses', and winiara 'a female lover of wine').

The terms that unequivocally valorise men include, among others, incel (from involuntarily celibate), stulejarz or przegryw (both referring to beta males), as well as words with non-gender connotations, e.g., szur (a radical) or foliarz (tinfoil hatter) 'a supporter of conspiracy theories'. The term impostor, derived from online games, replaced the nationwide 'oszust', atencjusz (from Eng. 'attention') is used to refer to "a person demanding constant attention", while kasztan (chestnut) is a variation of the good-natured dzban (jug/pitcher) — 'an individual with low intelligence'. The former 'adorator' and 'pantoflarz' are replaced by the terms simpa borrowed from the English original and indicating 'a man showing servile attitude towards the opposite sex' and bialorycerz (a hopeless simp towards all women), who observes political correctness. The term chad (borrowed from English) - the opposite of incel - evokes extreme emotions since it means an extremely handsome and well-built young man, an object of universal adoration but also arouses envy and pity among the representatives of the rest of the manosphere.

Youth speak includes not only negative terms to describe people but also those that prove the use of language as a space of fun and community relations. There are thus neologisms evoking neutral connotations, which occur in both masculine and feminine grammatical forms, e.g., typiarz/typiara; ziomal/ziomala or are double-gender, such as positively marked hotówna 'an attractive person' (cf. English 'hot').

The tendency to express and valorise people is reflected not only in social antagonisms between the genders. It is definitely gaining momentum in the 
context of contemporary unambiguous ideological and political divisions into prawacy 'people of right-wing, conservative and nationalistic views' and lewacy 'people of left-wing and equality views'. Both sides use language to negatively identify prawilni (US) and nieprawilni (OTHERS) and to be engaged in discussions and polemics - masakrowanie (gerund from 'to massacre') and zaorywanie (literally 'ploughing under'), i.e., to defeat one's ideological opponents in word fights (masakrować lewaków (to butcher leftards), or orać feministki (lit. 'plow feminists'), etc. - cf. Fal 2014. This binary division is part of the US-THEM pattern activated by the described language and developed on the common and undisputed cultural foundation. This foundation is defined as "the basis of all knowledge, intra- and intergroup, on which various ideologies are developed" (van Dijk 9) whereas individual communities and their discourses select those elements that influence their identity (cf. Skowronek 18).

This pattern includes not only social peer representations but also those from the prefigurative area (Mead). This applies, for example, to the youngadult relationship, especially in the field of marking the intergenerational distance. The slang terms used in the past to refer to the representatives of the older generations: dziad, jarecki, stary, starszy (all referring to 'old coot') nietoperz, wapniak (fossil, crumbly) have been replaced with a modern lexeme of boomer - 'a representative of the baby boom generation, an elderly person'. Therefore, the popular colloquial phrase "OK boomer!" appears as a pragmatically useful device to stop a conversation with an adult or as an expression of embarrassment about certain behaviour of an opponent (e.g., japa boomer). The neologism dziaders, less often dziadkers, from which young people distance themselves (cf. the definition presented in Miejski.pl dictionary of slang) is no longer a sign of age but of mental limitation and paternalistic tendencies. As we can read on the website Obserwatorium jezykowe $U W$ (Language Observatory of the University of Warsaw) it "colloquially and jokingly refers to a man, whose behaviour, views, tastes and way of being are perceived by the speaker as outdated or even archaic and who (in the speaker's opinion) cannot deal with contemporary social reality" (Obserwatorium). The artificiality of this structure is revealed against the lexemes used by adolescents, which belong to the class of personal nouns. While the names of people with suffix -er can be considered in youth speak as productive (e.g., loozer 'loser', moher 'an excessively pious person, conservative, backward', crusher 'a person admired by many' those with suffix -ers are definitely rarer. 
The given examples show that in the youngest Polish language, the phenomena of antagonization are used to create cognitive stereotypes. The linguistic effects of numerous interactions that young people participate in show that there are no relationships and behaviours without encoded, usually stigmatizing, meanings.

\section{MARKING RELATIONS}

Meanwhile, on the other extreme, there are those realizations which are justified by their phatic function. The tendency to maintain contact within a prestigious youth community (and more broadly with youth) by means of a specific language is justified in its capability of building identity. Experimenting with language is a safe form of channelling youthful contestation. It gives a sense of agency or provides a need for separateness as well as linguistic authenticity greatly appreciated by young people. This corresponds to the regularity of seeking self-identification of entities and provides a space for shaping identity. We are talking about the "bottom-up" process of identity formation in relation to community ties, preferences concerning spending free time or participating in culture. ${ }^{3}$ Not surprisingly, this register records numerous, constantly reproduced signs referring to maintaining contact. They appear in speech acts related to greeting, saying goodbye, maintaining or interrupting a conversation as well as retorting. They are also carriers of common sense of humour. The terms of this type: elo, eluwinaleluwa, siema, siemson, siemka, siemanko, nara, narka, narson (peace out, toddle-oo, pizzout) are very popular and subject to constant formal modifications. The motivation for coining them comes usually from the impression that such words become "outdated" and lose their expressive value as well as phatic power after they are disseminated in the general language.

The innovations which are useful in pragmatic contexts include also the exclamation neologism naura/naurra (approximately 12.3 thousand submissions to the Youth Word of the Year 2020 contest). It is a variation of the modern na razie (see you). What is more, this example illustrates a significant feature of the youngest Polish language, which is non-arbitrariness-semantic

\footnotetext{
${ }^{3}$ As indicated by Zbigniew Melosik, analysing the theory presented by John Fiske, two main ways of shaping identity are brought together in popular culture - the first ,top-down” one refers to regulating it according to the accepted assumptions whereas the second „bottom-down” one refers to self-identification (Melosik 23)
} 
lability. Looking at the contexts of the use of the term naura (as an appellative exclamation) it is obvious that it may appear not only in the form of a happy adolescent goodbye but also in the form of a device used to stop an unwanted contact: Powiedziatem, no i naura! Naura z toba! (peace out, man) (author's own collection). On the other hand, humorous phrases of byczku/byczq/byku (hey, hunk!) used in a conversation with a friend constitute not only an element of communicative fraternization or affection but also a manifestation of approval: Oj tak, byczq (+1); Jest dobrze byczq; Obczajamy byczku! Oj, tak, tak, dobrze widzisz byczku.

Form such as yikes (pronounced jajks) or yślyyś play the role of new paralinguistic signs in the community of young people, reflecting the entire spectrum of emotions in the reaction of the recipient of the messagesurprise, amazement, approval, embarrassment. On the other hand, there are the so-called retorts - conventionalized phrases that testify to the rhetorical dexterity of the interlocutor in the so-called "word fights". That is why they are considered to be dissy/disy 'replicas' and pociski (cf. slang pocisnać kogos/ komuś 'tease someone, make fun of someone'). They are used pragmatically to develop the relationship while disregarding the rules of linguistic etiquette, e.g., a strategy of respect for the conversation partner against the principle of diminishing the sender with simultaneous appreciation of the interlocutor (Ożóg 77). Miejski.pl has over 600 of them. Some are constituted by acts of ordering or threats, so they threaten the interpersonal bond, breaking unsatisfactory contact, e.g., bujaj się, faluj się, goń się leszczu, pal gumę/kapcia/ wrotki, ryj się, sklej pieroga/kapcia/wary, spadówa (go fry an egg; go soak your head; go soak yourself) while others intensify the effect of the recipient's depreciation by depriving them of the right to a good image and dignity: bujaj garba; chyba się z glupim przez ścianę macateś; Chyba spisz od ściany; Kij ci w szprychy; Kto cię wystrugat; Mama cię nie kocha; Nasikat ci ktoś kiedyś do oka? (variations of vulgar sod off).

An invasive communication strategy would probably intensify the effect of humiliation or intimidation of the recipient, were it not for the convention of "game or play", the existence of which is well recognized by the users of the youngest Polish language. Entering the game mode means that the domination over the interlocutor and the severity of the invective are weakened and expressive formulas are reduced to useful rhetorical tools.

Although invective structures are used as breakers of unsatisfactory contact, when silence of the interlocutor means winning a game, they also 
often function as witty retorts. ${ }^{4}$ Their role is then both to take on the challenge of participation in the game, thrown by the interlocutor, and to defeat the opponent by depriving them of the will to continue the conversation, as if against the interaction ritual. Examples of language tools used for this purpose, which are extremely popular among teenagers, include the following structures: twoja stara (your old woman): twoja stara kroi chleb tokciem (lit. your old woman cuts bread with her elbow), twoja stara jeździ winda po lesie (your old woman rides around a forest in a lift); and twój stary (your old man): twój stary zamiata pustynię (your old man sweeps a desert), twój stary pijany (your old man is drunk) (available at MaX Humor.pl). As one of the participants of the Youth Word of the Year 2020 contest explains: "This expression is used when there are no arguments. This is not to offend parents but only to prevent a lost quarrel". Retorts of this type are therefore mainly used for "the subjective expressiveness of the speakers, which [...] not only shows the emotional attitude towards the discussed topics but creates an appropriate psychological basis and atmosphere, allowing for complete selfrealization of the participants of the conversation" (Awdiejew and Habrajska 206). The popularity of the examples results not only from their pragmatic convenience but also from: 1) capacious ambiguity (contextual meaning), 2) ease of reproduction, 3) high emotive-evaluative load, and 4) absurd humour. This last aspect is characteristic of the register under discussion. It is not difficult to observe that the ludic character has become an expansive practice in the informal discourse of young people. The skill of humorous commenting and retorting, especially in the space of digitally mediated contact (cf. Mistrzowie.org), is one of the essential skills of participation in contemporary culture.

\section{MARKING EMOTIONS}

One of the important features of youth speak is marking the ludic and emotional attitude towards reality. Everything can be brought to a grotesque dimension and dismissed with laughter-its symbol is $x D / X D$ and its verbal version $i k d e$ 'laughter, joke, irony'. $X D$ - the youth word of the year 2017defines a whole spectrum of phenomena characteristic of homo ridens. The

\footnotetext{
${ }^{4} \mathrm{~A}$ witty retort that is an accurate response to a question, statement, provocation - as we read on nonsensopedia.wikia.com - "can silence the interlocutor and stop their desire to continue the discussion".
} 
popularity of this sign results from its semantic capacity and pragmatic function:

1. If we flip it horizontally, it creates something like an emoticon that closes its eyes with laughter. The word XD is used both in writing (when we are amused) or in conversations to make a comment. Young people, students and people up to 30 years of age use this sign, most often it is used by influencers.

2. A mocking sign added to a message that turns even the most serious message into a humorous one (Youth Word of the Year 2020).

Interestingly, the sign $\mathrm{xD} / \mathrm{XD}$, appearing first in the Internet as an equivalent of another very popular acronym $-L O L$ "Laugh Out Loud-a lot of laughter" has also become a symbol of the attitude towards life, known as the philosophy of $X D$ or iksdeizm (cf. Metzen). ${ }^{5}$ XD's philosophy is conceptualized in the context of experiencing reality, which is associated with a free, humorous and trivializing attitude to events, people or obligations. A manifestation of this attitude includes adding $x D$-as one of the users explains - at the end of a given story in order to emphasize the ridiculousness of the topic and the ease we feel when talking about it ("Koziar" on FCBarca.pl). Therefore, what evokes joy and a good mood in adolescent conceptualization is hyperbolized. This is evidenced by neologisms used in the function of exclamation marks or excitement markers, e.g., essa, gaziura, kox, mamale, appearing quite frequently in the contest's database. Like es/ez/ezz derived from English 'easy', they "easily" evoke pleasant experiences and positive emotions (reduplication of letters reflects the intensity of a specific feature). They are also an example of the role of linguistic consensus (Sierocka 2003) in determining meanings. The social perspective-the immersion in a phatic community (culturally shaped interpersonal practice) gives prerogatives to the correct interpretation of the meaning of these paralinguistic "grunts" (cf. Malinowski).

The same happens with economic structures, which in the Internet "written speech" of young people evolved from iconic signs, e.g., $U w U$ 'charming, delightful', pog/pogchamp; poggers 'excitement, joy, enthusiasm', SKSKS 'emotional reaction reflecting laughing mainly on TikTok and Instagram' or

${ }^{5}$ The author of the term, Sławomir Metzen, wrote about its meaning: "Since I started following the philosophy of XD, my life has become calmer.... When I encounter stressful situations, I think to myself: XD and everything becomes easier. I really recommend this lifestyle to everyone" (Metzen, fourth page of the cover). 
are the result of acronymization: $P O V$ for Eng. 'point of view', $R I G C Z$ 'human reason and dignity', $J D$ 'vulgar phrase', $F$ 'respect; showing compassion'. ${ }^{6}$ The meanings become concrete in the socio-cognitive community as an effect of jargon conventionalization, while outside it they are imprecise.

One of the most recognizable features of youth speak is expressiveness. Researchers claim that the youth register is a plus-minus language (Chaciński) that verbalizes experiences of the greatest emotional saturation. Numerous indicators subjectively valorizing reality are arranged in antagonized combinations of what is "great, sensational, pleasant", e.g., baza, fest, git, giga luz, igła, jazdunia, masno, sztos, srogo, and what is negatively perceived: cringe/krindż, żenuncja 'embarrassment, absurdity', fail, kaszana, masakra, przyps/przypat, oro, skifa, zamuła 'negative, bad event'. Young people are constantly looking for terms of experienced emotions, mainly the extreme ones, which gain new forms for fun, e.g., the popular ending -ówa/ówka/uwa/-uwka (gitówa/smakówa, krindżówa). When juxtaposed with the adverb fest, they undergo additional hyperbolization, e.g., smakówa fest.

The phenomenon of adolescent approach to life based on the hedonistic apotheosis of pleasure and avoidance of unpleasantness generates ludic behaviors, which can be located under the following entries: beka/beczka/bekowo 'comic event, a play with something or someone', heheszki 'onomatopoeia defining joking and mocking somebody or something', podśmiechujki 'a play on words referring to a Polish taboo word, meaning making jokes', pranki 'joking, fooling someone'. The mechanism of robienie beki is known, for example, from the carnival realizations of "the world upside down" (Bachtin, Bełkot), in which inverted values come to the fore. It is worth noting that the convention of communicative carnivalization ("speech in reverse") allows for speech acts such as mockery, stigmatization, and insult, which are unacceptable in mainstream culture and social politeness strategies. The young kultura beki is often realized in the area of aggressive humour, sometimes the so-called edge humour that depreciates persons and events, trivializing and vulgarizing experiences and cultural patterns. Interestingly, the conventionalization of humour within the youth communitas not only justifies but also "suspends" the strategies of linguistic politeness, allowing for linguistic behaviour alternative to mainstream culture. One of the effects is the uncompromising mocking social discourse by exposing vulgarity $(21,000$ submissions for the

\footnotetext{
${ }^{6}$ The sign comes from the game "Call of Duty" in which in order to pay tribute to someone, one had to press the F key" ("Młodzieżowe Słowo Roku" 2020)
} 
Youth Word of the Year 2020). They were "un-tabooed" after they hit the banners of street protests in autumn 2020. They also became a "back-up" for coining new words. A good example of this phenomenon is the travesty of one of the politically motivated vulgarism in the form of eight asterisks: ***** $* * *$. These, in turn, served as a derivative base for other language realizations, such as: the titles of musical works (Eight Stars, Karol Krupiak), names of anti-system groups (Eight Stars Movement), T-shirt inscriptions (******** on CupSell.pl).

\section{POPULAR CULTURE AS A SOURCE OF NEW TERMS}

Popular culture, especially digitally mediated culture, is a rich source of popular and "trendy" vocabulary. The mass character of subcultural styles means that within the youth community it is preferable to play with cultural signs and linguistic material. The influences of hip-hop with lexemes such as bankroll 'banknote', chillwagon 'name of a music group', halko (version of the telephone 'halo'), patointeligencja (a blend of pathology and inteligency, i.e., "difficult youth from the so-called good homes"), ${ }^{7}$ sztywno/sztywniutko (lit. rigidly) 'well', zajawa 'interest in something, passion' are still commonly used. The Internet is becoming a place where culture is created and displayed by streamers, YouTubers, influencers, and pranksters, who are becoming idols and creators of mass youth imagination. Their popularity also contributes to the assimilation of the linguistic structures they create. For example, the Internet eluwina (another transformation of hip-hop elo) entered teen communication as a variant of a greeting devised by YouTuber Kacper Blonsky. Words such as crusher, dzban, prestiżowy, naura, masny, mamale were brought to life by: Kacper Blonky, Klocuch, Lord Kruszwil, and Boxdel. The latter-also appearing in the Masno Gang music group - became famous for using the Silesian dialect as a source of linguistic creation. His popular streams resulted in the popularity of words and phrases such as: grzibi/gzibi 'stopy', jo cie chwyca 'declaration, surprise', lecymy durs 'further', and masno fest 'very well'.

Any area of culture can become a source of linguistic creation in youth speak. For example, the pathetic phrase rozum i godność czlowieka (reason

\footnotetext{
${ }^{7}$ The prefix pato- is used in youth speak to refer to phenomena, people or events which remain outside mainstream culture and typical image of the world, e.g., patobaza, patostreamer, patościeżka, patotrap, patowrażliwość, etc.
} 
and dignity of man) which first appeared on the religia.tv portal, gave rise to the popular $R i G C z / R I G C Z / r i g c z$ (acronym), which soon began to function as a sign of disapproval (Człowieku, trochę RiGCzu! Masz ty w sobie jakiś $R i G C z$ ?), objection (Bez RiGCz- u to chciateś ogarnać?) or admiration (Ten to ma dopiero $R i G C z$ !). The high level of $R i G C Z z$ is characteristic of individuals with high intellectual and moral potential - the so-called ludzie (humans) - as opposed to podludzie (subhumans; the singular is podludz'), and raki 'losers, fools'.

In turn, the community of computer players and users of newsgroups introduced vocabulary such as: banować 'exclude', czitować 'cheat', skin 'appearance', skile 'skills, abilities' to a wider 'circulation'. The Internet also gave rise to okejka 'approve', kampić 'hide', lagować 'delay', lajkować 'like', tryhardować 'try hard', stonks 'profit', sus 'suspicious', impostor 'cheater', noob 'unskilled person', OP/op 'a post publisher', SANS GRANIE 'ambiguous reference to a popular character from meme and fandom'. The corporate czelendżować (challenge) began to mean simply 'action' and 'striving for a goal' (Czelendzujemy ten wynik? - Shall we challenge this result?), whereas the acronym $A S A P$ 'as soon as possible' in some circles has become synonymous with the phrase on speed.

It is worth noting that the language material in the analysed register can be both Polish and English. Numerous English borrowings are translated into Polish. Additionally, their creative transformation takes place beyond the general norms of lexical assimilation. Playing with a linguistic sign takes place both on the level of content and form. It is especially easy for young language users in terms of adaptation and transformation of a morphological nature (cf. Mańczak-Wohlfeld). And so the proper borrowing of chill out 'relax, rest' gave rise to terms such as chill, chillera, chillax, chillować bombe, which occur within the system next to the completely assimilated forms: czill, czillera, czilaucik, cziloowa, czilować bombe 'rest, celebration'. Examples of ludic imitation of a foreign spelling (cf. Witalisz) when creating native neologisms include realizations such as: byq/byqu, beczooonia, dzięx, spox, sorx, imi3 (image), kisski (kiss), kanapkens as well as leżing, wtosing, śmieching, looz, looks, gloopi, formed with particles from the English language.

The principle of mówić inaczej (saying otherwise) is therefore associated with an inclination to the ludic mixing of many orders and styles. Postmodern variability, professionalism, collecting experiences and loose relationships together with the multiplicity of media identities favour spontaneous creation. This means the choice of means (linguistic material) from many alternative 
but equal spaces according to preferences and fashion in line with the slogan: pick and mix (Melosik 74). New structures are brought into synonymic ranks and used to "shade" meanings.

\section{CONCLUSIONS}

The above analyses show that contemporary Polish youth speak has quickly "tamed" the pandemic reality by means of a structure popular within expressive and ludic colloquial registers. After a short period of an explosion of derivatives naming both "new" elements of the Covid reality as well as people, objects or phenomena, there has been a return to structures marking various aspects of relationships, emotional experiences or the so-called "mocking culture". It seems that the need to establish virtual contacts by no means impoverished the youth language. On the contrary, it intensified everything that is ludic and extreme in it, contributing to the fact that youth speak "supports" both real and virtual colloquiality. It is the significant "intermediality" of youth lexis that deserves attention as it responds to the needs of the contemporary iGeneration, for which virtuality and reality are not separate areas but constitute a different dimension of the same reality, culture and language.

Summing up, it should be emphasized that the directions of development of youth lexis strictly depend on culturally shaped actions and human behavior. This cultural "scaffolding" gives support to teenage linguistic manifestations and the communicative emotional markers. It also makes it possible to produce creative, non-standard uses within the youth culture, dynamically enriching the system with derivations in which meanings come to life thanks to the relationships between the signs intuitively sensed by the participants of the communication. Connotative components, texturally implemented as essential elements of words, become an important building block of meanings. The ability to decode them is also one of the criteria for belonging to the community of "US".

Young people cultivate their environmental standards of progressing through youth, including the specificity of the way they communicate, and therefore even experiencing a pandemic does not change their lexical preferences. Although youth speak records new global phenomena and gives them an unequivocal value in language, it does not make them the centre of 
lexical creation. Structures naming people, social phenomena, emotions, or a way of being are much more exploited. The force of life again turned out to be so attractive that it overcame the fear of illness. At least among the young.

\section{WORKS CITED}

\section{LITERATURE}

Awdiejew, Alosza, and Grażyna Habrajska. Wprowadzenie do gramatyki komunikacyjnej. Oficyna Wydawnicza Leksem, 2006.

Bachtin, Michaił. Problemy poetyki Dostojewskiego. Translated by Natalia Modzelewska, Państwowy Instytut Wydawniczy, 1970.

Bartmiński, Jerzy. "Styl potoczny jako centrum systemu stylowego języka.” Synteza w stylistyce słowiańskiej, ed. Stanisław Gajda, Wydawnictwo WSP w Opolu, 1991, pp. 33-47.

Bełkot, Andrzej. "Karnawalizacja jako pojęcie ludyczne." Homo Communicativus, no. 2, 2008, pp. 45-57.

Chaciński, Bartłomiej. "Plus-minus język." Polityka. Niezbędnik Inteligenta: O języku w mowie i piśmie (special issue), no. 11, 2014, pp. 90-94.

Czarnecka, Małgorzata, Uczniowska odmiana współczesnej polszczyzny w świadomości jej użytkowników. WiS, 2000.

Dijk, Teun van. "Dyskurs polityczny i ideologia.” Etnolingwistyka, no. 15, 2003, pp. 7-28.

Fal, Michał. "Korwin masakruje...', czyli o politycznej karierze pewnego słowa." natemat.pl, 21 May 2014, natemat.pl/103155,korwin-masakruje-czyli-o-politycznej-karierze-pewnego-slowa\#>. Accessed 8 Feb. 2021.

Klimczyk, Wojciech. Erotyzm ponowoczesny. Universitas, 2008.

Grabias, Stanisław. Język w zachowaniach społecznych. Wydawnictwo UMCS, 2003.

Klus-Stańska, Dorota. Dydaktyka wobec chaosu pojęć i zdarzeń. Wydawnictwo Akademickie Żak, 2010.

Mańczak-Wohlfeld, Elżbieta. Angielsko-polskie kontakty językowe. Wydawnictwo UJ, 2006.

Malinowski, Bronisław. "Problem znaczenia w językach pierwotnych." Translated by Tadeusz Szczerbowski. Językoznawstwo Bronisława Malinowskiego, edited by Krystyna Pisarkowa, vol. 2, Universitas, 2000.

Majchrzyk, Łukasz. "Lista najpopularniejszych emoji związanych z koronawirusem." mobirank.pl, mobirank.pl/2020/03/15/emoji-koronawirus-covid-19. Accessed 10 Mar. 2021.

Mead, Margared. Kultura i tożsamość. Studium dystansu międzypokoleniowego. Translated by Jacek Hołówka, Wydawnictwo Naukowe PWN, 2000.

Melosik, Zbyszko. Kultura popularna i tożsamość młodzieży. W niewoli władzy i wolności. Kraków, 2013.

Metzen, Sławomir. Filozofia XD. Wydawnictwo 3DOM, 2020.

Ożóg. Kazimierz. Polszczyzna przełomu XX i XXI wieku. Wybrane zagadnienia, Stowarzyszenie "Fraza", 2001.

Pisarek, Walery. Polskie słowa sztandarowe i ich publiczność. Universitas, 2003. 
Sierocka, Beata, editor. Via communicandi. Przełom komunikacyjny a filozoficzna idea konsensu. Oficyna Wydawnicza Atut, 2003.

Skowronek, Bogusław. "Mediolingwistyka. Teoria. Metodologia. Idea." Poscriptum Polonistyczne, no. 2, 2014, pp. 15-26.

Skudrzyk, Aldona, and Krystyna Urban. "Mcdonaldyzacja, bigbrotheryzacja, czyli eponimy współczesne - norma ortograficzna i uzus." W kręgu zagadnień dydaktyki języka i literatury polskiej: księga jubileuszowa dedykowana Profesorowi Edwardowi Polańskiemu, edited by Helena Synowiec, Wydawnictwo Uniwersytetu Śląskiego, 2002, pp. 258-263.

Warchala, Jacek. Kategoria potoczności w języku. Wydawnictwo UŚ, 2003.

Wileczek, Anna. "Kidult (nie tylko) językowy.” Postscriptum Polonistyczne, no. 1, 2017, pp. 179-196.

Wileczek, Anna. Kod młodości. Młodomowa w aspektach społeczno-kulturowych. Wydawnictwo Naukowe PWN, 2018.

Wileczek, Anna. 'Kod młodzieży czy kod młodości? Społeczno-kulturowe aspekty 'mediatyzacji' młodomowy." Polszczyzna w dobie cyfryzacji, edited by Agata Hącia, Katarzyna Kłosińska, and Piotr Zbróg. Wydawnictwo Polskiej Akademii Nauk, 2021, pp. 169-186.

Witalisz, Alicja. Przewodnik po anglicyzmach w języku polskim. TMJP, 2016.

Widawski, Maciej. "Twentieth Century American Slang and Its Sociocultural Context. Part One.” Kwartalnik Neofilologiczny, no. 3, 2012, 381-391.

\title{
INTERNET SOURCES
}

jeja.pl, teksty.jeja.pl/332,twoja-stara.html. Accessed 10 Feb. 2021.

FCBarca.pl, www.fcbarca.com/la-rambla/dyskusja-8500066. Accessed 10 Feb. 2021.

MaxHumor.pl, maxhumor.pl/teksty/Twoj_Stary-85.html. Accessed 10 Nov. 2020.

Uniwersytet Warszawski. Obserwatorium Językowe Uniwersytetu Warszawskiego, nowewyrazy.uw.edu.pl/ haslo/to-stan-umyslu.html. Accessed 30 Jan. 2021.

Słownik slangu. Miejski.pl, www.miejski.pl. Accessed 3 Jan. 2021.

"Młodzieżowe Słowo Roku." sjp.pwn.pl, sjp.pwn.pl/mlodziezowe-slowo-roku/plebiscyt-pwn-mlodziezoweslowo-roku;202298.html. Updated 1 May. 2021.

“Janusz.” sjp.pwn.pl, sjp.pwn.pl/ciekawostki/haslo/Janusz-janusz;5899758.html. Updated 9 Dec. 2016. PWN Dictionary of the Polish Language, sjp.pwn.pl/. Accessed 10 Dec. 2021.

"XD / skarpety." nadwyraz.com, nadwyraz.com/xd-skarpety. Accessed 15 Feb. 2021.

\author{
(NON)PANDEMIC YOUTH SPEAK. \\ ON LEXICAL-SEMANTIC TENDENCIES \\ IN THE POLISH LANGUAGE OF THE YOUTH
}

Sum mary

This article presents the latest lexical tendencies in the language of contemporary Polish youth. The directions of the dominance of certain meanings were analysed on the basis of the submissions for the Youth Word of the Year contest (2020), as well as the online slang dictionary miejski.pl. The data obtained comes from natural users of the language and is based on their linguistic awareness and 
intuition. Dominant semantic fields were distinguished, namely human, interpersonal relationships, attitudes towards life, cultural preferences, etc. Coining new terms in these areas is accompanied by expressiveness, humour, and playing with language norms. Despite the occurrence of new words connected with the Covid-19 pandemic, they have not been widely represented among those lexical and semantic units considered interesting and worth mentioning.

Keywords: youth speak; lexis of youth sociolect; youth slang; pandemic; pandemic vocabulary; coronavirus.

(NIE)PANDEMICZNA MOWA MŁODYCH

O TENDENCJACH LEKSYKALNO-SEMANTYCZNYCH W POLSZCZYŹNIE MŁODZIEŻY

$$
\text { Streszczenie }
$$

W artykule przedstawiono najnowsze tendencje leksykalne w języku współczesnej polskiej młodzieży. Kierunki dominacji niektórych znaczeń przeanalizowano na podstawie zgłoszeń do plebiscytu Młodzieżowe Słowo Roku (2020) oraz internetowego słownika slangu Miejski.pl. Dlatego uzyskane dane pochodzą od użytkowników języka naturalnego i opierają się na ich świadomości językowej i intuicji. Na tej podstawie można wyróżnić dominujące pola semantyczne: człowiek, relacje międzyludzkie, postawy życiowe, preferencje kulturowe itp. Twórczości językowej z tych dziedzin towarzyszy ekspresja, humor i zabawa z normami językowymi. Pomimo występowania nowych słów związanych z pandemią koronawirusa, nie zyskały one szerokiej reprezentacji wśród jednostek leksykalno-semantycznych uznanych za interesujące i godne wyróżnienia.

Słowa kluczowe: młodomowa; leksyka socjolektu młodzieżowego slang; slang młodzieżowy; pandemia; słownictwo w czasie pandemii; koronawirus. 